\title{
Steady-state pharmacokinetics of delavirdine in HIV-positive patients: Effect on erythromycin breath test
}

\begin{abstract}
Objective: The steady-state kinetics of delavirdine and desisopropyldelavirdine were evaluated in human immunodeficiency virus-positive patients after escalating oral doses and after repeated oral administrations at the same dose level.

Study design: Patients ( $n=8$ males) were given escalating oral doses of delavirdine mesylate, in a sequential fashion, over 14 days for phases 1 ( $200 \mathrm{mg}$ every 8 hours), 2 ( $300 \mathrm{mg}$ every 8 hours), and 3 ( $400 \mathrm{mg}$ every 8 hours). Control patients ( $n=4$ males) were given $300 \mathrm{mg}$ oral doses of druy every 8 hours for all three phases. Hepatic CYP3A activity was evaluated with the erythromycin breath test (ERMBT).

Results: In the escalating-dose group, delavirdine displayed nonlinear kinetics as indicated by the decreasing oral clearance, maximum steady-state plasma concentration/minimum steady-state plasma concentration ratio, and log-linear terminal rate constant, as well as by the increasing half-life at higher doses; the ratio of desisopropyl-delavirdine formation clearance to elimination clearance was also reduced. In the control group, the kinetics of delavirdine and desisopropyl-delavirdine were unchanged. Plasma protein binding was linear for delavirdine in the escalating-dose and control groups; on average, the fraction unbound was about $2.3 \%$ and $2.0 \%$, respectively. Hepatic CYP3A activity was markedly reduced after short- and long-term exposure to all doses of delavirdine mesylate. Delavirdine could maximally inhibit $70 \%$ to $75 \%$ of predose ERMBT values, with an IC50 of about $0.9 \mu \mathrm{mol} / \mathrm{L}$.

Conclusion: Delavirdine is a potent and reversible inhibitor of hepatic CYP3A; it is also a substrate for this CYP450 isoform. It is likely that delavirdine will exhibit drug-drug interactions when coadministered with other CYP3A substrates. (Clin Pharmacol Ther 1997;61:531-43.)
\end{abstract}

Ching-Ling Cheng, MS, David E. Smith, PhD, Peggy L. Carver, PharmD, Steven R. Cox, PhD, Paul B. Watkins, MD, Debbie S. Blake, BS, Carol A. Kauffman, MD, Katherine M. Meyer, RN, Gordon L. Amidon, PhD, and Philip L. Stetson, MD, PhD Ann Arbor and Kalamazoo, Mich.

The bisheteroarylpiperazines (BHAPs) are a class of non-nucleoside compounds that have been shown to inhibit the reverse transcriptase of human immunodeficiency virus (HIV) type 1 (HIV-1) and to

From the College of Pharmacy, Upjohn Center for Clinical Pharmacology, and the Department of Pharmacology and the Department of Internal Medicine, Medical School, the University of Michigan and Veterans Affairs Medical Center, Ann Arbor, and Pharmacia \& Upjohn Inc., Kalamazoo.

Supported in part by a grant from Pharmacia \& Upjohn Inc. (Kalamazoo, Mich.), and by grants R01 GM35498 and M01 RR00042 from the National Institutes of Health (Bethesda, Md.). Received for publication July 1, 1996; accepted Nov. 15, 1996. Reprint requests: David E. Smith, PhD, Upjohn Center for Clinical Pharmacology, 1310 E. Catherine St., University of Michigan, Ann Arbor, MI 48109-0504.

13/1/79280 block HIV-1 replication in cell culture. ${ }^{1-6}$ These compounds are highly specific inhibitors of HIV-1 reverse transcriptase (RT), having no activity against the RT of HIV-2 or the other animal retroviruses. ${ }^{5,6}$ As a member of this class of compounds, delavirdine acts exclusively as a mixed inhibitor of both the RNA- and DNA-directed DNA polymerase domains of the RT enzyme. ${ }^{7}$ In this capacity, delavirdine has a much higher binding affinity for the enzyme-substrate complex than for the free enzyme and, as a result, it does not directly impair the function of the substrate binding site.

During clinical development, it was observed that delavirdine had a nonlinear disposition in human subjects, so that single-dose kinetics could not be used to accurately predict the steady-state plasma concentrations of drug. ${ }^{8,9}$ However, these studies 
Table I. Demographic data for HIV-positive patients

\begin{tabular}{|c|c|c|c|c|c|c|c|c|c|c|}
\hline $\begin{array}{c}\text { Patient } \\
\text { No. }\end{array}$ & $\begin{array}{c}\text { Group/ } \\
\text { gender } \\
\text { race }\end{array}$ & $\begin{array}{c}\text { Age } \\
(y r)\end{array}$ & $\begin{array}{c}\text { Body } \\
\text { weight } \\
\text { (kg) }\end{array}$ & $\begin{array}{c}\text { Smoker } \\
\text { status' }\end{array}$ & $\begin{array}{c}C D 4 \\
\left.\text { (cells/mm }{ }^{3}\right)\end{array}$ & $\begin{array}{c}A L T \\
\text { (units/L) }\end{array}$ & $\begin{array}{c}A S T \\
\text { (units/L) }\end{array}$ & $\begin{array}{c}A L B \\
(\mathrm{gm} / \mathrm{dl})\end{array}$ & $\begin{array}{c}B U N \\
(m g / d l)\end{array}$ & $\begin{array}{c}S C R \\
(m g / d l)\end{array}$ \\
\hline 1 & $2 / \mathrm{M} / \mathrm{W}$ & 28 & 118 & \pm & 299 & 52 & 42 & 4.6 & 19 & 1.2 \\
\hline 2 & $1 / \mathrm{M} / \mathrm{W}$ & 31 & 60.2 & \pm & 339 & 38 & 31 & 4.6 & 12 & 1.1 \\
\hline 3 & $2 / \mathrm{M} / \mathrm{W}$ & 24 & 65.9 & + & 81 & 26 & 23 & 4.4 & 22 & 1.2 \\
\hline 4 & $2 / \mathrm{M} / \mathrm{W}$ & 25 & 67.4 & + & 571 & 36 & 35 & 4.8 & 9 & 0.9 \\
\hline 5 & $1 / \mathrm{M} / \mathrm{W}$ & 36 & 69.1 & \pm & 259 & 61 & 56 & 4.3 & 9 & 0.8 \\
\hline 6 & $1 / \mathrm{M} / \mathrm{B}$ & 35 & 66.8 & \pm & 329 & 67 & 89 & 3.6 & 11 & 0.7 \\
\hline 7 & $1 / \mathrm{M} / \mathrm{W}$ & 43 & 73.6 & + & 27 & 133 & 92 & 3.7 & 7 & 0.7 \\
\hline 8 & $1 / \mathrm{M} / \mathrm{B}$ & 38 & 75.0 & + & 130 & 35 & 36 & 4.0 & 9 & 1.0 \\
\hline 9 & $1 / \mathrm{M} / \mathrm{W}$ & 31 & 101 & + & 10 & 115 & 145 & 3.9 & 13 & 0.8 \\
\hline 10 & $2 / \mathrm{M} / \mathrm{W}$ & 33 & 90.0 & \pm & 259 & 35 & 36 & 4.3 & 13 & 1.0 \\
\hline 11 & $1 / \mathrm{M} / \mathrm{B}$ & 32 & 62.8 & + & 4 & 35 & 26 & 3.9 & 16 & 0.9 \\
\hline 12 & $1 / \mathrm{M} / \mathrm{W}$ & 32 & 70.9 & - & 271 & 32 & 24 & 3.9 & 13 & 1.1 \\
\hline Mean & & 32 & 76.7 & & 215 & 55 & 53 & 4.2 & 13 & 1.0 \\
\hline SD & & 5 & 17.4 & & 170 & 34 & 37 & 0.4 & 4 & 0.2 \\
\hline
\end{tabular}

M, Male; B, black; W, white; +, active smoker; \pm , previous smoker; -, nonsmoker; CD4, initial T-lymphocyte cell count; ALT, alanine aminotransferase; AST, aspartate aminotransferase; ALB, serum albumin; BUN, blood urea nitrogen; SCR, serum creatinine.

were performed using different subjects for each dose level, thus complicating the interpretation of pharmacokinetic data among treatment groups. More importantly, the data offered no insight into the mechanism of dose-dependent kinetics. In vitro studies in liver microsomes from several animal species (including human) have shown that the major metabolic pathway of delavirdine is $N$-dealkylation, a process catalyzed primarily by cytochrome $\mathbf{P} 450$ 3A (CYP3A) isoforms. ${ }^{10}$ Further, it appears that delavirdine may inhibit CYP3A through a mechanism-based process. As a result, it is possible that the in vivo clearance of delavirdine may be attenuated as a consequence of capacity-limited kinetics, as well as by diminished enzymatic capacity.

With this in mind, the objectives of the proposed study were (1) to define the steady-state pharmacokinetics of delavirdine and its $N$-desisopropyl metabolite in IIIV-positive patients after escalating oral doses and after repeated oral administrations at the same dose level, (2) to determine the in vivo effect of delavirdine mesylate on CYP3A activity in liver, and (3) to cstablish the rclationship between hepatic CYP3A activity in vivo and delavirdine plasma concentrations.

\section{METHODS}

Patient population. Patients with written documentation of HIV-1 infection were enrolled in the study. Patients ranged in age from 24 to 43 years, in body weight from 60.2 to $118 \mathrm{~kg}$, and in initial CD4 counts from 4 to $571 \mathrm{cells} / \mathrm{mm}^{3}$. Nine of the patients were white and three of the patients were black. Six patients were active smokers, five were previous smokers, and one patient was a nonsmoker. None of the patients had acute medical problems or histories of clinically significant disease (e.g., renal, hepatic, cardiovascular, gastrointestinal, or neurologic). In addition, patients were not taking any drugs known to be enzyme inducers or inhibitors. ${ }^{11}$ The most commonly coadministered medications were acetaminophen (paracetamol; five patients), trimethoprimsulfamethoxazole (five patients), zidovudine (four patients), dapsone (three patients), ibuprofen (two patients) and acyclovir (aciclovir; two patients). Individual demographic data are provided in Table I. All study protocols were approved by the Institutional Review Board of the University of Michigan Medical School, and written consent was obtained from each patient.

Study design. The protocol for this study specified an open-label, parallel-group, multiple-dose pharmacokinetic study in adult HIV-positive male or femalc paticnts. Patients in group 1 ( $n=8$ males) were given escalating oral doses of delavirdine mesylate, in a sequential fashion, for phases 1,2 , and 3 . In phase 1, patients were given $200 \mathrm{mg}$ delavirdine mesylate (two $100 \mathrm{mg}$ tablets) every 8 hours for 14 days. On day 15, a full pharmacokinetic study was performed immediately after the morning dose. In phase 2, patients were given $300 \mathrm{mg}$ delavirdine mesylate (three $100 \mathrm{mg}$ tablets) every 8 hours for 14 
days (days 17 through 30 ), and on day 31 a full pharmacokinetic study was performed after the morning dose. In phase 3, patients were given 400 $\mathrm{mg}$ delavirdine mesylate (four $100 \mathrm{mg}$ tablets) every 8 hours for 14 days (days 33 through 46), and on day 47 a full pharmacokinetic study was performed after the first dose. Patients in group 2 ( $n=4$ males) were given $300 \mathrm{mg}$ oral doses of delavirdine mesylate (three $100 \mathrm{mg}$ tablets) every 8 hours for all three phases.

On days 15 and 31 (the first two pharmacokinetic assessments), serial blood samples $(3 \mathrm{ml})$ were obtained at time 0 (predose) and at $1 / 4,1 / 2,3 / 4,1,1 \frac{1}{2}, 2$, $2 \frac{1}{2}, 3,4,5,6,8,10,12,16,24$, and 48 hours after dosing. For the $1,2,4,6$, and 8 hour postdose samples, an additional $5 \mathrm{ml}$ blood sample was obtained for protein binding determinations. On day 47 (the third pharmacokinetic assessment), serial blood samples were obtained as described above, with an additional sample taken at 72 hours after dosing. Blood volumes were also obtained for protein binding determinations as described above. Trough plasma concentrations ( $3 \mathrm{ml}$ blood samples) were monitored on designated days during the 54day study period. Blood was drawn from a forearm vein, by venipuncture or an indwelling catheter, into heparin-containing Vacutainer tubes ( $3 \mathrm{ml}$ samples) or ethylenediaminetetraacetic acid-containing Vacutainer tubes ( $5 \mathrm{ml}$ samples). Blood samples were centrifuged immediately and the plasma was harvested. After the plasma was heated for 30 minutes at $56^{\circ} \mathrm{C}$ (except in those samples for protein binding determinations), samples were frozen $\leq-20^{\circ} \mathrm{C}$.

Patients were admitted to the General Clinical Research Center on the nights before pharmacokinetic assessments and were not allowed to eat or drink anything (except water) at least 6 hours before dosing. Two hours after delavirdine was administered, patients were given 6 ounces of orange juice. A standardized lunch and dinner was provided 4 and 10 hours after dosing, and all beverages were decaffeinated.

Erythromycin breath test. Several erythromycin breath tests were performed in each patient to assess the temporal and drug-related effects on CYP3A activity in the liver and the resultant effects on delavirdine kinetics. The erythromycin breath test (ERMBT) was performed just before the start of the delavirdine study (day 1) and during drug administration on the mornings of days 2 and 14 (i.e., 24 hours after initiating the first dose rate and at steady state for phase 1), days 18 and 30 (i.e., 24 hours after initiating the second dose rate and at steady state for phase 2), days 34 and 46 (i.e., 24 hours after initiating the third dose rate and at steady state for phase 3 ), and after washout from the last previous dose (day 50 or 54 or both). Each patient received the ERMBT a total of 8 to 9 times, as described previously. ${ }^{12,13}$ In brief, patients were given $3 \mu \mathrm{Ci} \quad(<0.1 \mu \mathrm{mol})$ of $\left[{ }^{14} \mathrm{C}-\mathrm{N}\right.$ methyl] erythromycin intravenously while at rest, and breath samples were collected before and $20 \mathrm{~min}$ utes after injection. The expired ${ }^{14} \mathrm{CO}_{2}$ was measured by liquid scintillation counting. Breath test results are expressed as the percent of administered ${ }^{14} \mathrm{C}$ exhaled during the first hour after injection of erythromycin, as estimated by a single breath collection obtained at 20 minutes.

Heidelberg capsules. Delavirdine is a weakly basic amine $(\mathrm{pKa} \cong 4.5)$ that may exhibit dissolutionlimited absorption because of its poor aqueous solubility at elevated $\mathrm{pH}$ values.* Moreover, the decreased gastric acid secretion observed in some patients with acquired immunodeficiency syndrome (AIDS) could result in poor or erratic oral drug performance. ${ }^{14}$ With this is mind, gastric $\mathrm{pH}$ was monitored on the days that pharmacokinetic assessments were performed (i.e., days 15, 31, and 47) with the Heidelberg capsule, a nondigestible radiotelemetric indicalor of gastrointestinal $\mathrm{pH} .{ }^{15,16} \mathrm{In}$ brief, at approximately 30 minutes before drug dosing, the Heidelberg capsule, tethered to a string, was positioned in the stomach with the aid of $90 \mathrm{ml}$ water. Its position was verified by fluoroscopy after the first treatment (day 15) and by the measured length of tether for subsequent treatments. The oral delavirdine dose was then administered with 8 ounces of water, and continuous radiotelemetric measurements were made for an additional 4 hours (for a total of $4 \frac{1}{2}$ hours). After these measurements, the capsule was retrieved orally.

Analytical procedures. Delavirdine (MW 456.6) and its $N$-desisopropyl metabolite (MW 414.5) were quantitated simultaneously in human plasma with use of a sensitive and specific HPLC assay with fluorescence detection. ${ }^{17}$ Calibration curves were constructed over a low plasma concentration range ( 25 to $5000 \mathrm{ng} / \mathrm{ml}$ ) and over a high plasma concentration range $(100$ to $25,000 \mathrm{ng} / \mathrm{ml})$. Quality control samples $(50,100,400,800,4000$, and $20,000 \mathrm{ng} / \mathrm{ml})$

\footnotetext{
*Investigator brochure for delavirdine mesylate: a nonnucleoside reverse transcriptase inhibitor. Pharmacia \& Upjohn Inc., Kalamazoo, Mich., July 1995.
} 
Phase 1

Phase 2

Phase 3

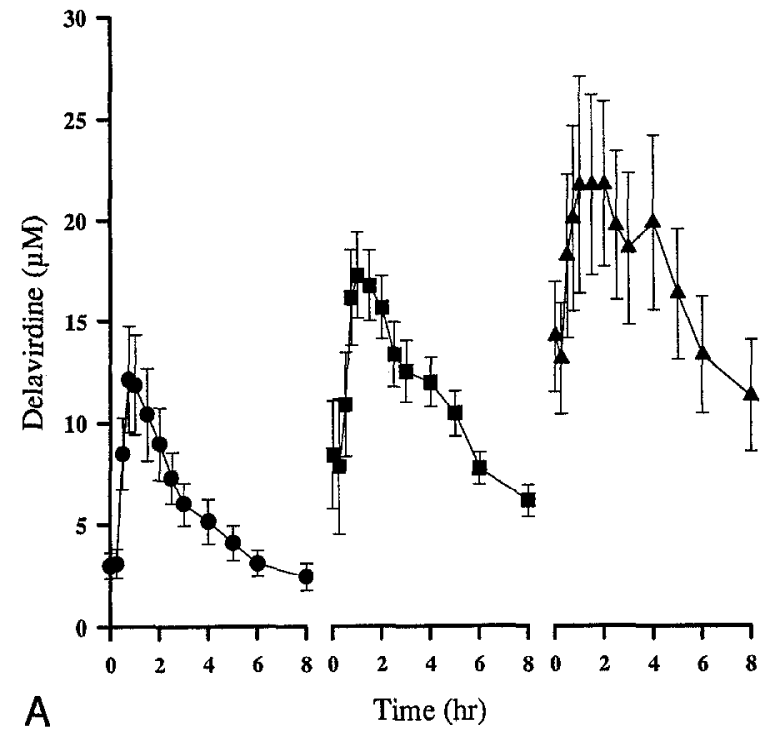

Phase 1

Phase 2

Phase 3

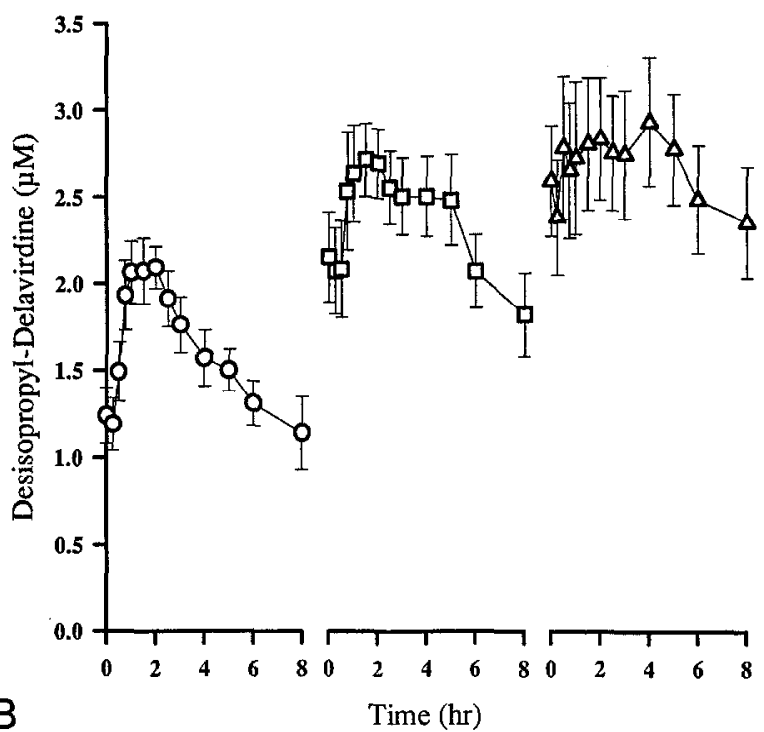

Fig. 1. Plasma concentration-time profiles for delavirdine (A) and desisopropyl-delavirdine (B) in the escalating-dose group of HIV-positive patients (group 1). Data reported as mean values $\pm \mathrm{SE}(n=7)$.

were run for drug and metabolite over a 5-day period. Overall, the precision ( $\%$ coefficient of variation [\%CV]) and accuracy (\% bias) of the assay were $\leq 9.7 \%$ and $\leq 9.2 \%$, respectively.

For those samples that contained dapsone, the assay was modified to separate delavirdine desiso-
Phase $1 \quad$ Phase 2 Phase 3

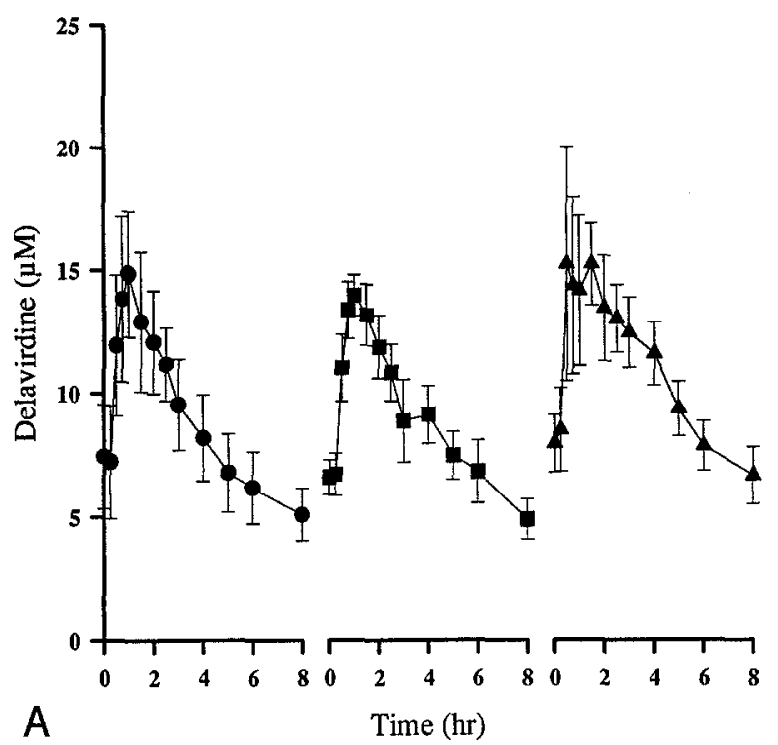

Phase 1

Phase 2

Phase 3

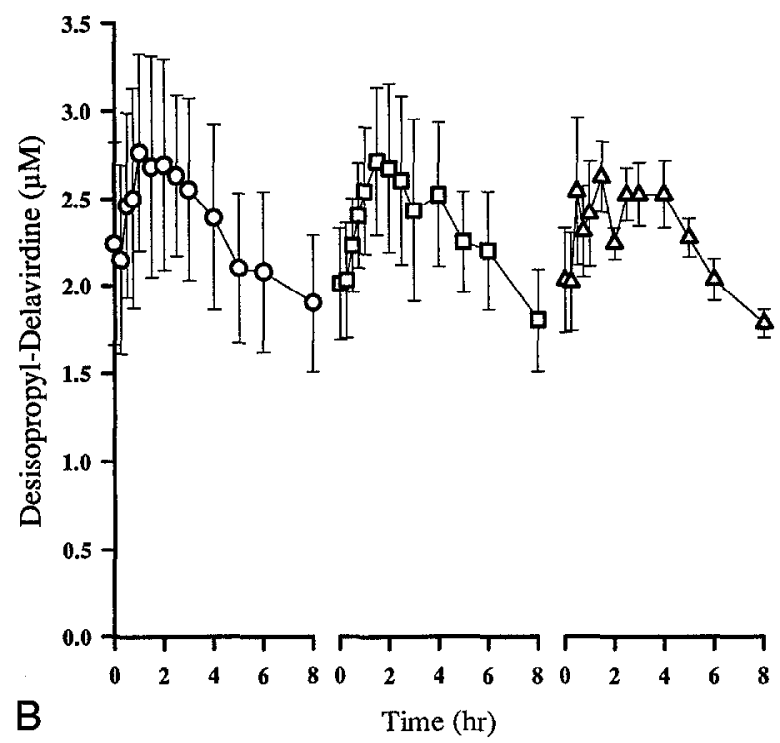

Fig. 2. Plasma concentration-time profiles for delavirdine (A) and desisopropyl-delavirdine (B) in the control group of HIV-positive patients (group 2). Data reported as mean values $\pm \operatorname{SE}(n=4)$.

propyl metabolite, dapsone, and dapsone monoacetyl metabolite. Minor modifications included a change in the mobile phase to $10 \mathrm{mmol} / \mathrm{L}$ monobasic potassium phosphate ( $\mathrm{pH}$ 6.0)/acetonitrile/methanol (20:7:7) and a reduction in the volume of buffer (from 400 to $300 \mu$ l) mixed with supernatant solu- 
Table II. Delavirdine pharmacokinetics after oral dosing of delavirdine mesylate at $200 \mathrm{mg}$ every 8 hours (day 15, phase 1), $300 \mathrm{mg}$ every 8 hours (day 31, phase 2), and $400 \mathrm{mg}$ every 8 hours (day 47, phase 3 )

\begin{tabular}{lcccc}
\multicolumn{1}{c}{ Parameters } & Day 15 & Day 31 & Day 47 & Friedman's test \\
\hline $\mathrm{CL} / \mathrm{F}(\mathrm{L} / \mathrm{hr})$ & $14.5 \pm 17.6$ & $7.85 \pm 6.07$ & $7.79 \pm 5.95$ & $p=0.0498$ \\
$\mathrm{C}_{\mathrm{av}}^{\mathrm{ss}}(\mu \mathrm{mol} / \mathrm{L})$ & $5.56 \pm 2.89$ & $11.1 \pm 4.01 \dagger$ & $17.0 \pm 8.71 \dagger$ & $p=0.0021$ \\
$\mathrm{C}_{\min }^{\mathrm{ss}}(\mu \mathrm{mol} / \mathrm{L})$ & $1.98 \pm 1.20$ & $5.79 \pm 2.52 \dagger$ & $10.1 \pm 5.41 \dagger$ & $p=0.0021$ \\
$\mathrm{C}_{\max }^{\mathrm{ss}}(\mu \mathrm{mol} / \mathrm{L})$ & $12.6 \pm 6.70$ & $18.8 \pm 7.23^{*}$ & $26.6 \pm 12.9 \dagger$ & $p=0.0058$ \\
$\mathrm{t}_{\max }(\mathrm{hr})$ & $0.93 \pm 0.28$ & $1.37 \pm 0.78^{*}$ & $2.23 \pm 1.69^{*}$ & $p=0.0361$ \\
$\mathrm{C}_{\mathrm{max}}^{\mathrm{ss}} / \mathrm{C}_{\mathrm{min}}^{\mathrm{ss}}$ ratio & $8.42 \pm 5.29$ & $3.77 \pm 1.65 \dagger$ & $2.75 \pm 0.90 \dagger$ & $p=0.0038$ \\
$\left.\lambda_{\mathrm{z}}(\mathrm{hr})^{-1}\right)$ & $0.277 \pm 0.053$ & $0.222 \pm 0.065^{*}$ & $0.188 \pm 0.064 \dagger$ & $p=0.0119$ \\
$\mathrm{t}_{1 / 2}(\mathrm{hr})$ & $2.59 \pm 0.53$ & $3.33 \pm 0.89^{*}$ & $4.12 \pm 1.52 \dagger$ & $p=0.0119$ \\
$\mathrm{CL}_{\mathrm{form}} / \mathrm{CL}_{\text {met }}$ ratio & $0.401 \pm 0.293$ & $0.244 \pm 0.127 \dagger$ & $0.197 \pm 0.106 \dagger$ & $p=0.0021$ \\
$\mathrm{f}_{\mathrm{u}}(\%)$ & $2.29 \pm 0.31$ & $2.38 \pm 0.33$ & $2.33 \pm 0.32$ & $p=0.3679$ \\
\hline
\end{tabular}

Data are reported as mean values $\pm \mathrm{SD}(n=7)$.

${ }^{*} p \leq 0.10, \dagger p \leq 0.05$ when day 31 or day 47 is compared with day 15 (Wilcoxon signed-rank test using Bonferroni-adjusted $p$ values).

$\mathrm{CL} / \mathrm{F}$, Oral clearance; $\mathrm{C}_{\mathrm{av}}^{\mathrm{ss}}$, average steady-state plasma concentration; $\mathrm{C}_{\mathrm{min}}^{\mathrm{ss}}$, minimum steady-state plasma concentration; $\mathrm{C}_{\mathrm{max}}^{\mathrm{ss}}$ maximum steady-state plasma concentration; $t_{\max }$, time to reach $C_{\max } ; \lambda_{z}$, log-linear terminal rate constant; $t_{1 / 2}$, half-life; $C_{\text {form }}$, metabolite formation clearance; $C L_{\text {mer }}$, metabolite elimination clearance; $f_{u}$, fraction unbound.

Table III. Desisopropyl-delavirdine pharmacokinetics after oral dosing of delavirdine mesylate at $200 \mathrm{mg}$ every 8 hours (day 15, phase 1), $300 \mathrm{mg}$ every 8 hours (day 31, phase 2), and $400 \mathrm{mg}$ every 8 hours (day 47, phase 3)

\begin{tabular}{lcccc}
\hline \multicolumn{1}{c}{ Parameters } & Day 15 & Day 31 & Day 47 & Friedman's test \\
\hline $\mathrm{C}_{\mathrm{av}}^{\mathrm{ss}}(\mu \mathrm{mol} / \mathrm{L})$ & $1.57 \pm 0.36$ & $2.34 \pm 0.59 \dagger$ & $2.69 \pm 0.89 \dagger$ & $p=0.0021$ \\
$\mathrm{C}_{\min }^{\mathrm{ss}}(\mu \mathrm{mol} / \mathrm{L})$ & $0.946 \pm 0.333$ & $1.79 \pm 0.62 \dagger$ & $2.15 \pm 0.73 \dagger$ & $p=0.0038$ \\
$\mathrm{C}_{\max }^{\mathrm{ss}}(\mu \mathrm{mol} / \mathrm{L})$ & $2.18 \pm 0.41$ & $2.88 \pm 0.60^{*}$ & $3.23 \pm 0.98 \dagger$ & $p=0.0119$ \\
$\mathrm{t}_{\max }(\mathrm{hr})$ & $1.68 \pm 0.55$ & $1.84 \pm 1.60$ & $3.59 \pm 2.57$ & $p=0.5073$ \\
$\mathrm{C}_{\operatorname{mad}}^{\mathrm{ss}} / \mathrm{C}_{\min }^{\mathrm{ss}}$ ratio & $2.63 \pm 1.16$ & $1.69 \pm 0.31 \dagger$ & $1.54 \pm 0.22^{*}$ & $p=0.0211$ \\
$\lambda_{\mathrm{z}}(\mathrm{hr})$ & $0.158 \pm 0.043$ & $0.121 \pm 0.032^{*}$ & $0.101 \pm 0.032 \dagger$ & $p=0.0058$ \\
$\mathrm{t}_{1 / 2}(\mathrm{hr})$ & $4.71 \pm 1.51$ & $6.18 \pm 1.98^{*}$ & $7.50 \pm 2.44 \dagger$ & $p=0.0058$
\end{tabular}

Data are reported as mean values $\pm \mathrm{SD}(n=7)$.

${ }^{*} p \leq 0.10, \dagger p \leq 0.05$ when day 31 or day 47 is compared with day 15 (Wilcoxon signed-rank test using Bonferroni-adjusted $p$ values).

tion from extracted plasma. Under these conditions, dapsone (2.1 minutes) and dapsone monoacetyl metabolite ( 2.4 minutes) were eluted first, followed by delavirdine desisopropyl metabolite (2.7 minutes), the internal standard U-88,822 (6.6 minutes) and delavirdine (7.3 minutes). Quality control samples $(40,400,4000$, and $20,000 \mathrm{ng} / \mathrm{ml})$ were run for drug and metabolite over a 14-day period. Overall, the precision (\% CV) and accuracy (\% bias) of the assay were $\leq 4.3 \%$ and $\leq 8.8 \%$, respectively.

Protein binding. The in vivo binding of delavirdine to plasma proteins was determined with use of radiolabeled drug and an equilibrium dialysis method. The radiolabel was prepared as ${ }^{14} \mathrm{C}$-delavirdine mesylate, with a specific activity of $44.4 \mu \mathrm{Ci} / \mathrm{mg}$ and radiochemical purity $>99 \%$ (lot No. 27792-EHD38D). Samples were prepared by adding $10 \mu \mathrm{l} \mathrm{ra-}$ diolabeled drug (after appropriate dilution with methanol) to $1.0 \mathrm{ml}$ plasma so that counts were obtained in the region of $55,000 \mathrm{dpm} / \mathrm{ml}$. Plasma samples and isotonic phosphate buffer $(0.067 \mathrm{~mol} / \mathrm{L}$, $\mathrm{pH}$ 7.4) were preequilibrated to $37^{\circ} \mathrm{C}$ before loading, and $0.75 \mathrm{ml}$ plasma was then dialyzed against an equal volume of buffer for 6 hours at $37^{\circ} \mathrm{C}$ with Spectrapor 2 membrane tubing. Radioactive measurements for ${ }^{14} \mathrm{C}$-drug were performed on a liquid scintillation counter after mixing $200 \mu 1$ dialyzed plasma or buffer with $5 \mathrm{ml}$ scintillation fluid. An external standard method was used for quench correction, with a counting time of 10 minutes or $<2 \%$ error.

Data analysis. Pharmacokinetic parameters were calculated for delavirdine and its $\mathrm{N}$-desisopropyl metabolite with use of a noncompartmental approach. ${ }^{18}$ The half-life $\left(t_{1 / 2}=0.693 / \lambda_{z}\right)$ was detcrmined by linear regression with use of at least four data points from the log-linear terminal phase of the curve; $\lambda_{z}$ is the log-linear terminal rate constant. The steady-state area under the plasma concentration- 
Table IV. Delavirdine pharmacokinetics after oral dosing of delavirdine mesylate at $300 \mathrm{mg}$ every 8 hours (day 15, phase 1), $300 \mathrm{mg}$ every 8 hours (day 31, phase 2), and $300 \mathrm{mg}$ every 8 hours (day 47, phase 3 )

\begin{tabular}{|c|c|c|c|c|}
\hline Parameters & Day 15 & Day 31 & Day 47 & Friedman's test \\
\hline $\begin{array}{l}\mathrm{CL/F}(\mathrm{L} / \mathrm{hr}) \\
\mathrm{C}_{\text {av }}^{\mathrm{ss}}(\mu \mathrm{mol} / \mathrm{L}) \\
\mathrm{C}_{\min }(\mu \mathrm{mol} / \mathrm{L}) \\
\mathrm{C}_{\max }^{\mathrm{ss}}(\mu \mathrm{mol} / \mathrm{L}) \\
\mathrm{t}_{\max }(\mathrm{hr}) \\
\mathrm{C}_{\max }^{\mathrm{ss}} / /_{\mathrm{min}}^{\mathrm{Ss}} \text { ratio } \\
\lambda_{z}\left(\mathrm{hr}^{-1}\right) \\
\mathrm{t}_{1 / 2}(\mathrm{hr}) \\
\mathrm{CL}_{\mathrm{frrm}} / \mathrm{CL}_{\text {met }} \text { ratio } \\
\mathrm{f}_{\mathrm{u}}(\%)\end{array}$ & $\begin{array}{c}9.44 \pm 5.39 \\
8.63 \pm 3.50 \\
4.95 \pm 2.08 \\
15.2 \pm 5.3 \\
1.25 \pm 0.84 \\
3.21 \pm 0.46 \\
0.210 \pm 0.048 \\
3.47 \pm 0.97 \\
0.276 \pm 0.056 \\
2.14 \pm 0.50\end{array}$ & $\begin{array}{c}8.06 \pm 1.77 \\
8.75+2.00 \\
4.88 \pm 1.64 \\
14.6 \pm 1.4 \\
0.93 \pm 0.42 \\
3.18 \pm 0.73 \\
0.200 \pm 0.023 \\
3.51 \pm 0.45 \\
0.266 \pm 0.069 \\
2.04 \pm 0.55\end{array}$ & $\begin{array}{c}6.73 \pm 2.00 \\
10.7+2.9 \\
6.55 \pm 2.23 \\
18.4 \pm 6.7 \\
1.13 \pm 0.75 \\
2.82 \pm 0.30 \\
0.199 \pm 0.053 \\
3.66 \pm 0.95 \\
0.226 \pm 0.074 \\
1.90 \pm 0.52\end{array}$ & $\begin{array}{l}p=0.7788 \\
p=0.7788 \\
p=0.4724 \\
p=0.7788 \\
p=0.6456 \\
p=0.4724 \\
p=0.7788 \\
p=0.7788 \\
p=0.1738 \\
p=0.0183\end{array}$ \\
\hline
\end{tabular}

Data are reported as mean values $\pm \operatorname{SD}(n=4)$

${ }^{*} p \leq 0.10, \dagger p \leq 0.05$ when day 31 or day 47 is compared with day 15 (Wilcoxon signed-rank test using Bonferroni-adjusted $p$ values).

Table V. Desisopropyl-delavirdine pharmacokinetics after oral dosing of delavirdine mesylate at $300 \mathrm{mg}$ every 8 hours (day 15, phase 1), $300 \mathrm{mg}$ every 8 hours (day 31, phase 2), and $300 \mathrm{mg}$ every 8 hours (day 47, phase 3)

\begin{tabular}{|c|c|c|c|c|}
\hline Parameters & Day 15 & Day 31 & Day 47 & Friedman's test \\
\hline $\mathrm{C}_{\mathrm{av}}^{\mathrm{ss}}(\mu \mathrm{mol} / \mathrm{L})$ & $2.31 \pm 0.98$ & $2.32 \pm 0.73$ & $2.27 \pm 0.27$ & $p=0.7788$ \\
\hline $\mathrm{C}_{\min }^{\mathrm{ss}}(\mu \mathrm{mol} / \mathrm{L})$ & $1.85 \pm 0.78$ & $1.80 \pm 0.59$ & $1.72 \pm 0.24$ & $p=0.7788$ \\
\hline $\mathrm{C}_{\max }^{\mathrm{Ss}}(\mu \mathrm{mol} / \mathrm{L})$ & $2.87 \pm 1.08$ & $2.77 \pm 0.86$ & $2.86 \pm 0.52$ & $p=0.3679$ \\
\hline $\mathrm{t}_{\max }(\mathrm{hr})$ & $1.63 \pm 0.75$ & $1.62 \pm 0.47$ & $1.50 \pm 1.15$ & $p=0.9394$ \\
\hline $\mathrm{C}_{\max }^{\mathrm{ss}} / C_{\min }^{\mathrm{ss}}$ ratio & $1.59 \pm 0.19$ & $1.55 \pm 0.14$ & $1.67 \pm 0.13$ & $p=0.7788$ \\
\hline$\lambda_{\mathrm{z}}\left(\mathrm{hr}^{-1}\right)$ & $0.0957 \pm 0.0227$ & $0.110 \pm 0.010$ & $0.100 \pm 0.024$ & $p=0.3679$ \\
\hline $\mathrm{t}_{1 / 2}(\mathrm{hr})$ & $7.54 \pm 1.66$ & $6.32 \pm 0.59$ & $7.19 \pm 1.60$ & $p=0.3679$ \\
\hline
\end{tabular}

Data are reported as mean values $\pm \operatorname{SD}(n=4)$.

${ }^{*} p \leq 0.01, \dagger p \leq 0.05$ when day 31 or day 47 is compared with day 15 (Wilcoxon signed-rank test using Bonferroni-adjusted $p$ values).

time curve $\left(A U C_{\tau}^{\text {ss }}\right)$ was determined over the dosing interval, $\tau$ (i.e., from time zero to 8 hours), with use of a combination of the trapezoidal and log-trapezoidal rules. The average steady-state plasma concentration was then calculated as follows: $C_{\mathrm{av}}^{\mathrm{ss}}=\mathrm{AUC}_{\tau}^{\mathrm{ss}} / \tau$. The minimum $\left(\mathrm{C}_{\min }^{\mathrm{ss}}\right)$ and maximum $\left(\mathrm{C}_{\mathrm{max}}^{\mathrm{ss}}\right)$ plasma concentrations and the time to reach the maximum concentration $\left(t_{\max }\right)$ were determined by visual inspection of the data. Fluctuation ratio was then calculated as Fluc $=\mathrm{C}_{\max }^{\mathrm{ss}} / \mathrm{C}_{\min }^{\mathrm{ss}}$. The oral clearance of delavirdine was calculated as $\mathrm{CL} / \mathrm{F}=\mathrm{D} / \mathrm{AUC}_{\tau}^{\mathrm{ss}}$, in which $\mathrm{D}$ is the oral delavirdine dose, CL is the total plasma clearance, and $F$ is the fraction of administered dose systemically available. The ratio of desisopropyl-delavirdine formation clearance to elimination clearance was determined as $\mathrm{CL}_{\text {form }} / \mathrm{CL}_{\text {met }}=\mathrm{AUC}_{\tau \text { (desisopropyl-delavirdine) }}^{\text {ss }}$ $\mathrm{AUC}_{\tau}^{\mathrm{sS}}$ (delavirdine).

Protein binding analyses were performed on plasma samples from pharmacokinetic assessment days (i.e., days 15,31 , and 47 ) at 1, 2, 4, 6, and 8 hours after dosing. No evidence of nonlinear plasma protein bind- ing was observed for delavirdine in any of the samples tested. Therefore its unbound fraction (expressed as percentage) was determined as follows:

$$
\mathrm{f}_{\mathrm{u}}(\%)=100 \cdot \mathrm{Cf}^{\prime} /\left(\mathrm{Cf}^{\prime}+\mathrm{Cb}^{\prime \prime}\right)
$$

in which $\mathrm{Cf}^{\prime}$ is the unbound concentration of drug in buffer after dialysis, and $\mathrm{Cb}^{\prime \prime}$ is the volume-corrected bound concentration of drug in the postdialysis plasma. ${ }^{19}$ In a given treatment, the unbound fraction for each patient represents the mean of four to five determinations.

The relationship between ERMBT values and delavirdine plasma concentration (C) was analyzed for each patient with use of a modified $E_{\max }$ model:

$$
\mathrm{E} / \mathrm{E}_{0}=100-\mathrm{I}_{\max } \cdot \mathrm{C} /\left(\mathrm{IC}_{50}+\mathrm{C}\right)
$$

in which $E_{0}$ is the baseline effect for ERMBT in the absence of drug, $E / E_{0}$ is the observed effect for ERMBT in the presence of drug (expressed as a percent of control), $I_{\max }$ is the maximum inhibitory effect on ERMBT caused by the drug (expressed as 
a percent of inhibition), and $\mathrm{IC}_{50}$ is the delavirdine concentration (expressed as $\mu \mathrm{mol} / \mathrm{L}$ ) that produces $50 \%$ of the maximum inhibitory effect. Unknown parameters $\left(\mathrm{I}_{\max }\right.$ and $\left.\mathrm{IC}_{50}\right)$ were obtained with use of the nonlinear least-squares regression program Scientist for Windows version 2.0 (MicroMath Scientific Software, Salt Lake City, Utah), with a weighting factor of unity.

Data are reported as mean values \pm SD unless otherwise indicated. For each parameter, statistical differences were determined between treatments (or phases) by Friedman's test, followed by the Wilcoxon signed-rank test using Bonferroni-adjusted $p$ values. All statistical computations were performed with SYSTAT version 5.2 (Systat Inc., Evanston, Ill.).

\section{RESULTS}

Pharmacokinetics. Plasma concentrations obtained during the 0 - to 8-hour dosing interval on pharmacokinetic assessment days (i.e., days 15, 31, and 47) represent steady-state values for delavirdine and its $N$-desisopropyl metabolite (Figs. 1 and 2). In the escalating-dose group, delavirdine displayed nonlinear kinetics as indicated by the decreasing $\mathrm{CL} / \mathrm{F}, \mathrm{C}_{\max }^{\mathrm{ss}} / \mathrm{C}_{\min }^{\mathrm{ss}}$ ratio, and $\lambda_{z}$, as well as by the increasing $t_{1 / 2}$ at higher doses (Table II). It also appears that the $\mathrm{N}$-desisopropyl metabolite was produced at reduced levels relative to the amount of delavirdine present in plasma. Thus, at higher doses the ratio of desisopropyl-delavirdine formation clearance to elimination clearance $\left(\mathrm{CL}_{\mathrm{form}} / \mathrm{CL}_{\mathrm{met}}\right)$ was significantly reduced, suggesting a saturable metabolic pathway for delavirdine $N$-dealkylation. Protein binding of delavirdine was not dose dependent, and the fraction unbound averaged about $2.3 \%$ for each treatment. The desisopropyl metabolite of delavirdine also displayed nonlinear kinetics, as indicated by its decreasing $\mathrm{C}_{\max }^{\mathrm{ss}} / \mathrm{C}_{\min }^{\mathrm{ss}}$ and $\lambda_{\mathrm{z}}$ and by its increasing $\mathrm{t}_{1 / 2}$ at higher doses (Table III). Patient 9 was excluded from these analyses because of noncompliance with the study protocol.

In the control group, the kinetics of delavirdine and dcsisopropyl-delavirdine were unchanged after repeated administrations of the same dose during three different phases of multiplc-drug dosing (Tables IV and $\mathrm{V}$, respectively). Thus it appears that, on average, the kinetics of $300 \mathrm{mg}$ delavirdine mesylate (given orally three times a day) were reproducible over this time period. However, there was one exception. In this regard, the fraction unbound for delavirdine was statistically different over the three different phases. This
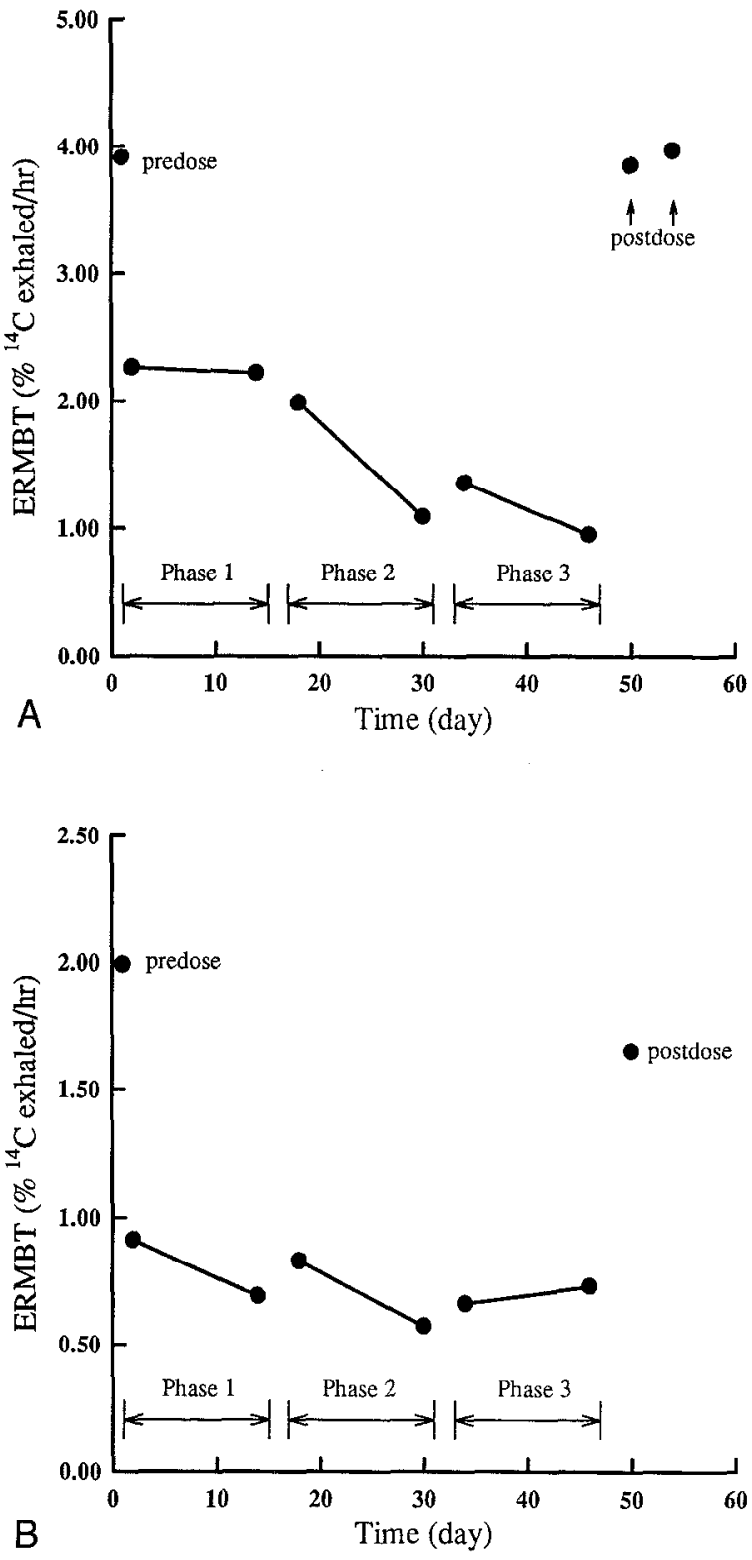

Fig. 3. Relationship between the erythromycin breath test (ERMBT) and time for patient 5 (escalating-dose group; $\mathbf{A}$ ) and patient 10 (control group; B). Samples were obtained before dosing and 1 and 13 days after initiation of each of the three treatment phases. A, Escalating-dose group: phase 1, $200 \mathrm{mg}$ every 8 hours; phase 2, $300 \mathrm{mg}$ every 8 hours; phase $3,400 \mathrm{mg}$ every 8 hours. B, Control group: phase $1,300 \mathrm{mg}$ every 8 hours; phase 2, $300 \mathrm{mg}$ every 8 hours; phase $3,300 \mathrm{mg}$ every 8 hours.

change was considered to be unimportant in that its reduction over time was on the order of only $11 \%$ and the change was not reflective of nonlinear plasma protein binding (compare with Table II). 


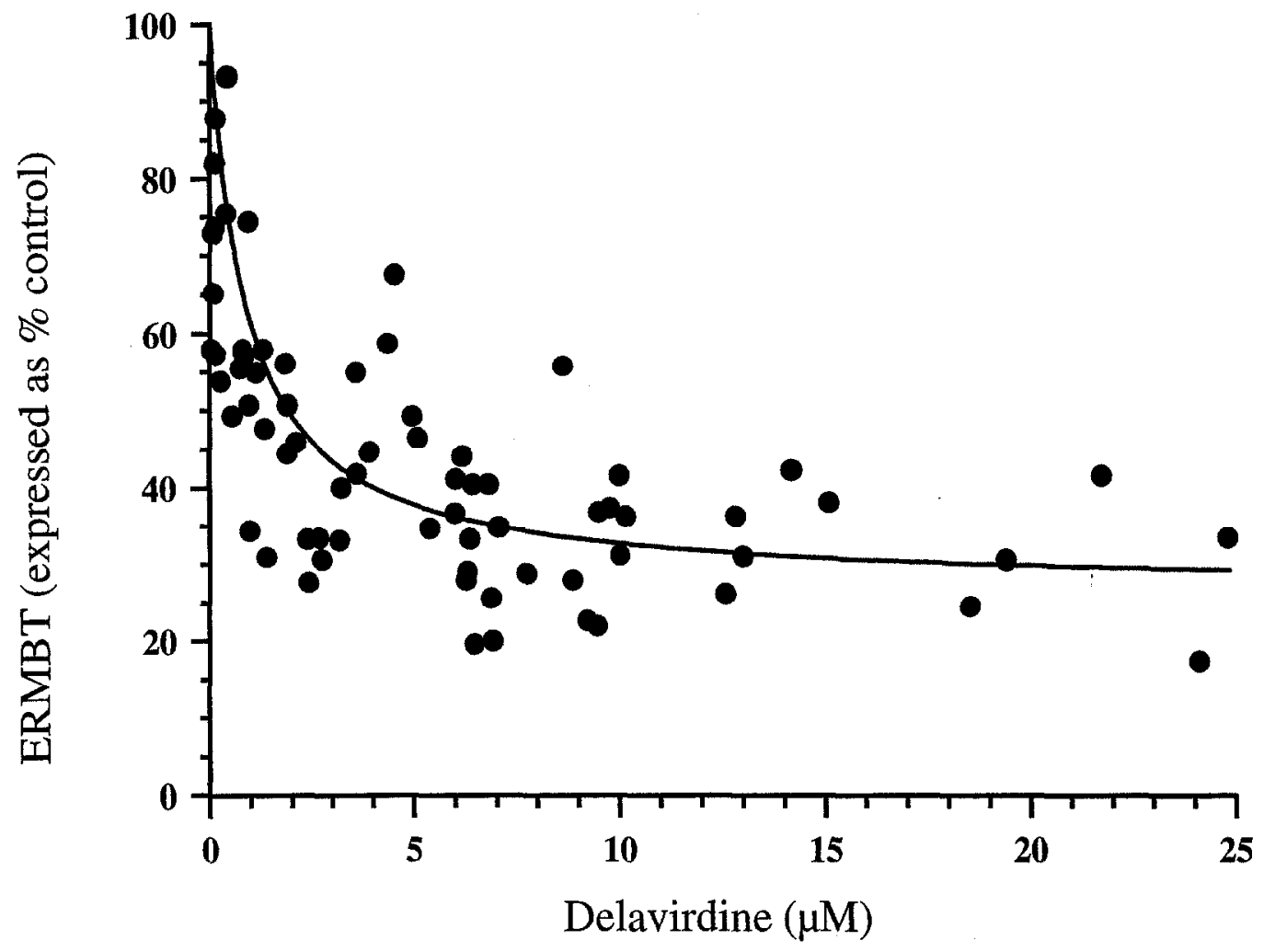

Fig. 4. Relationship between the ERMBT and delavirdine plasma concentrations with use of pooled data. The solid line represents the computer-simulated curve based on mean values for the fitted parameters in Table VI.

Table VI. Parameter estimates for inhibition of the erythromycin breath test (ERMBT) by delavirdine plasma concentrations

\begin{tabular}{ccccc}
\hline $\begin{array}{c}\text { Patient } \\
\text { No. }\end{array}$ & $\begin{array}{c}\text { Predose ERMBT } \\
\left(\%{ }^{14} \text { C exhaled/hr) }\right.\end{array}$ & $\begin{array}{c}I_{\max } \\
(\% \text { inhibition })\end{array}$ & $\begin{array}{c}\text { IC } \\
(\mu \mathrm{mol} / L)\end{array}$ & $r^{2}$ \\
\hline 1 & 3.31 & $85.3(7.1)$ & $1.49(0.50)$ & 0.9048 \\
2 & 4.53 & $80.9(1.6)$ & $0.370(0.056)$ & 0.9581 \\
3 & 4.83 & $76.7(2.0)$ & $0.0538(0.0124)$ & 0.9326 \\
4 & 1.69 & $67.8(11.4)$ & $2.96(1.74)$ & 0.5802 \\
5 & 3.91 & $76.5(2.0)$ & $0.626(0.064)$ & 0.9794 \\
6 & 2.43 & $71.8(2.8)$ & $0.825(0.215)$ & 0.8872 \\
7 & 1.66 & $62.6(2.0)$ & $0.463(0.142)$ & 0.8212 \\
8 & 3.09 & $76.3(14.9)$ & $0.360(0.218)$ & 0.7767 \\
10 & 2.31 & $64.3(6.2)$ & $0.128(0.044)$ & 0.8332 \\
11 & 1.99 & $73.0(3.8)$ & $0.753(0.285)$ & 0.7368 \\
12 & 2.48 & $77.5(11.2)$ & $1.80(0.83)$ & 0.9057 \\
Mean \pm SD & 1.80 & $67.5(1.4)$ & $0.832(0.119)$ & 0.9614 \\
\hline
\end{tabular}

See text for model.

Values in parentheses represent the standard deviation of individual parameter estimates. $r^{2}$ is the coefficient of determination.

ERMBT. Exposure to oral doses of delavirdine mesylate resulted in a rapid and substantial reduction in CYP3A activity in the liver for all patients. This is clearly shown by the representative exam- ples depicted in Fig. 3. As observed for patient 5 (Fig. 3, $A$; escalating-dose group), there was a monotonic decline in hepatic CYP3A activity as larger doses of drug were administered and as 
duration of drug administration increased from 1 to 14 days. In a similar fashion, hepatic CYP3A activity was reduced for patient 10 (Fig. 3, B; control group) after delavirdine administration, with the effect being greater at steady state than after 1 day of dosing. After washout from the body, ERMBT measurements returned to their predose values within 3 days, indicating that inhibition of hepatic CYP3A was rapidly and completely reversible.

As shown in Table VI, $I_{\max }$ and $\mathrm{IC}_{50}$ could be estimated reasonably well in each of the 12 patients. On average, the predose value for ERMBT was 2.84 , with $70 \%$ to $75 \%$ being maximally inhibited by delavirdine, which had an $\mathrm{IC}_{50}$ of about $0.9 \mu \mathrm{mol} / \mathrm{L}$. A large intersubject variability was also observed in some of the parameter estimates. Thus the variability, expressed by $\% \mathrm{CV}$ and range, was $38.7 \%$ (2.9-fold range) for predose ERMBT, 9.3\% (1.4-fold range) for $I_{\max }$, and $93.5 \%$ (55.0-fold range) for $\mathrm{IC}_{50}$. Although there was little variability in the maximum inhibitory effect of delavirdine, variability in the sensitivity to drug (i.e., $\mathrm{IC}_{50}$ ) was substantial. The overall relationship between ERMBT and delavirdine plasma concentrations is displayed in Fig. 4 with use of pooled data. Patient 9 was included in this analysis because assurance of steady-state levels was not a requirement.

A significant positive correlation was observed between ERMBT and the logarithm of the desisopropyl-delavirdine/delavirdine plasma concentration ratios with pooled data (Fig. 5; $r=$ $0.7908 ; p<0.0001$ ), showing that delavirdine is also a substrate for hepatic CYP3A. An even stronger correlation was observed when comparisons were made in individual patients (mean $\pm \mathrm{SD} ; r=$ $0.9253 \pm 0.0635 ; n=12$ ). Thus, as hepatic CYP3A activity was reduced (as indicated by the smaller values for ERMBT), less desisopropyl metabolite was formed relative to a given concentration of delavirdine.

Heidelberg capsules. Group 1 (escalating-dose) and group 2 (control) paticnts had gastric $\mathrm{pH}$ values that were between 1 and 2 for all three phases (Fig. 6; phasc 1 data shown). The $\mathrm{pH}$ was somewhat elevated after the oral dose of delavirdinc given with 8 ounces of water, and after the ingestion of 6 ounces of orange juice given 2 hours after dosing. These effects were of short duration, with $\mathrm{pH}$ values returning to baseline in about $1 / 2$ hour. In contrast, patient 11 had a substantially

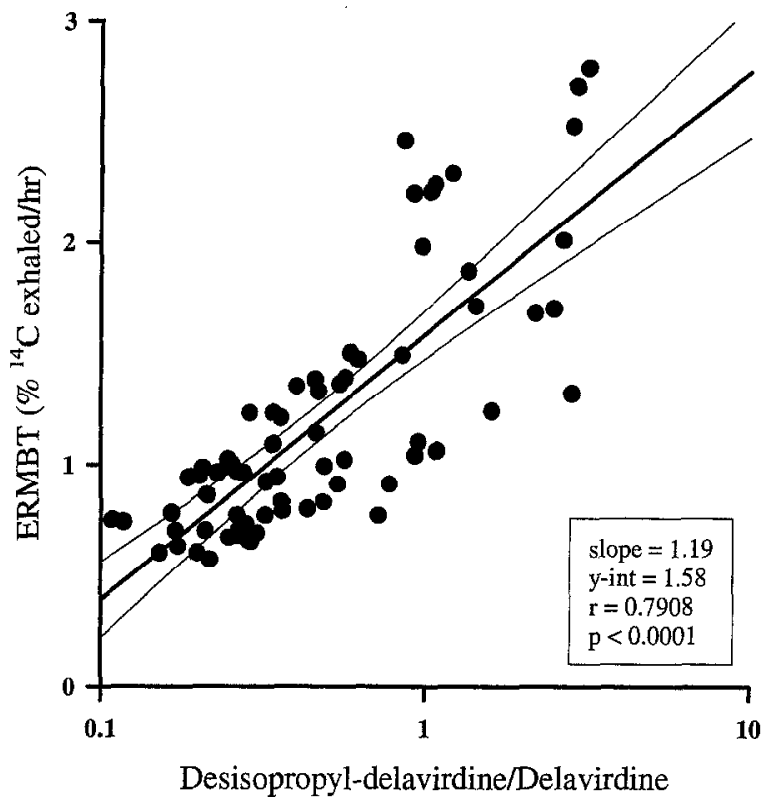

Fig. 5. Linear correlation between the ERMBT and the logarithm of desisopropyl-delavirdine:delavirdine plasma concentration ratios using pooled data. Confidence intervals ( $95 \%)$ have been added to the regression line.

elevated $\mathrm{pH}$ versus time profile for all three phases of drug administration. This particular patient had gastric $\mathrm{pH}$ values that were generally between 4 and 6 for the first 2 hours after the dose. After ingesting 6 ounces of orange juice, his $\mathrm{pH}$ dropped to values consistent with groups 1 and 2. Nevertheless, the kinetic parameters of patient 11 were not unusual compared with other patients in the escalating-dose group or compared with the control group after the $300 \mathrm{mg}$ dose. Patient 9 was not included in these analyses because correct positioning of the Heidelberg capsule was inadvertently not verified by fluoroscopy and, as a result, the data werc considercd to be unreliable.

Safety. Delavirdine was well tolerated under the conditions of this study, with no scrious medical events reported. The most frequently reported cvents werc rash (43\%) and headache $(36 \%)$. Patients completing the study received the drug through the rash with the exception of onc paticnt requiring treatment with hydroxyzine. All but one instance of rash had resolved by the end of the study. The remaining rash resolved within 2 weeks of the end of the study. 


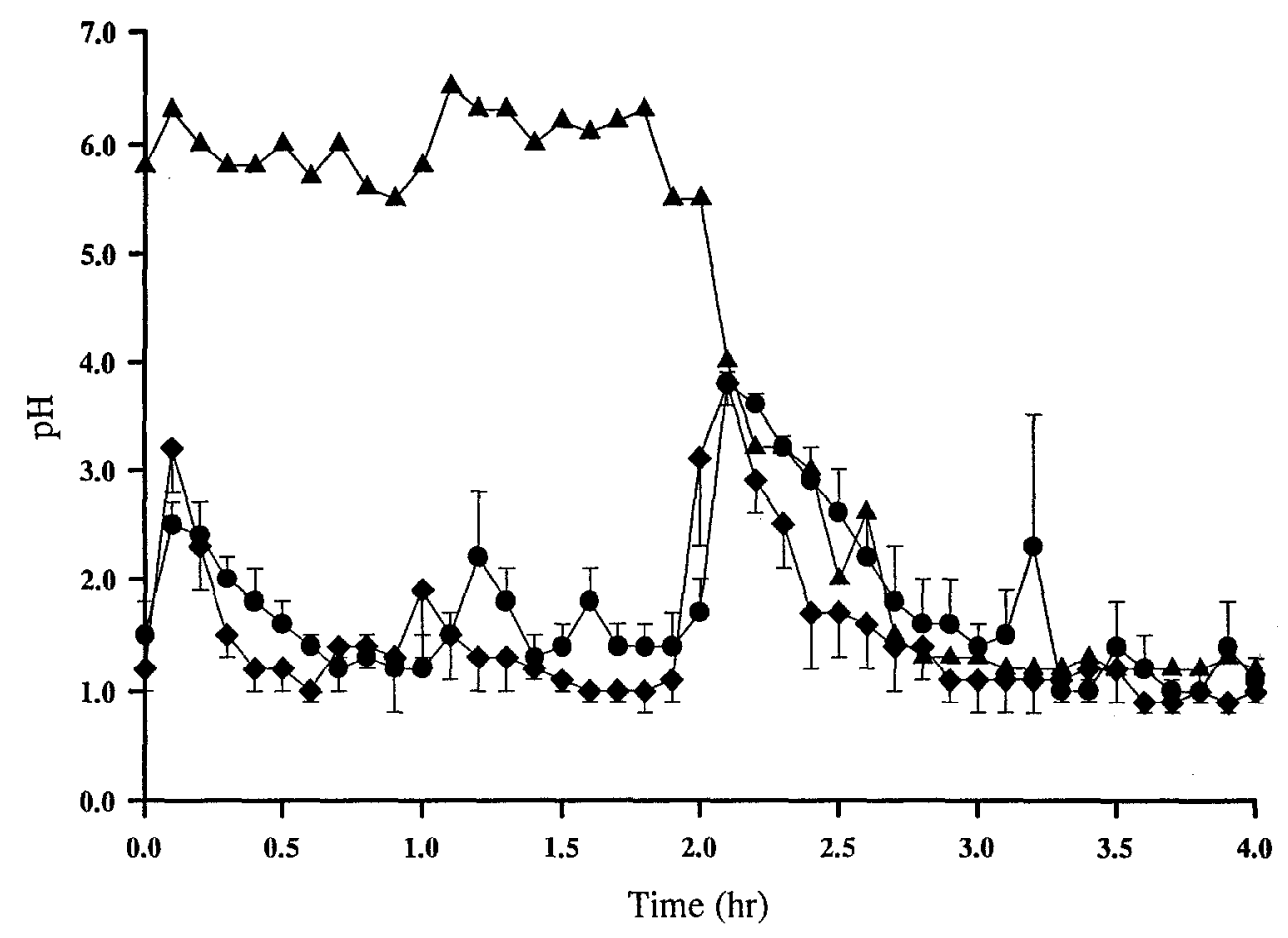

Fig. 6. Gastric $\mathrm{pH}$ versus time profiles for patients in the escalating-dose group $(n=6$; diamonds), the control group ( $n=4$; circles) and patient 11 (triangles) during the phase 1 treatment. Group data are reported as mean values $\pm \mathrm{SE}$.

\section{DISCUSSION}

Dclavirdinc has becn shown to have nonlincar pharmacokinetics in human subjects. ${ }^{*}$ In an escalating multiplc-dosc study in hcalthy voluntecrs (daily oral doses of 60 to $400 \mathrm{mg}$ ), there was a 15 -fold decrease in delavirdinc oral clearance, a thrcefold increase in half-life, and a fivefold decrease in the ratio of $\mathrm{N}$-desisopropyl metabolite formation clearance to metabolite elimination clearance over the dose range studied. ${ }^{8}$ A similar trend was observed during escalating multiple doses in HIV-positive patients. ${ }^{9}$ However, these studies were performed in parallel, with different patients participating at each dose level. In the present multiple-dose crossover study, delavirdine was escalated over a more limited range (i.e., daily oral doses of 600,900 , and $1200 \mathrm{mg}$ ). Under these conditions, there was considerable between- and within-subject variability in delavirdine kinetics, as illustrated in Fig. 7. Still, the oral clearance of delavirdine was observed to decrease by about $45 \%$ at the larger dose rates (Table II).

\footnotetext{
*Investigator brochure for delavirdine mesylate: a nonnucleoside reverse transcriptase inhibitor. Pharmacia \& Upjohn Inc., Kalamazoo, Mich., July 1995.
}

Because delavirdine was administered only by the oral routc, its reduced oral clcarance may reflcct either a decrease in total plasma clearance, an increase in systemic availability, or both.

Support for a decrease in the total plasma clearance of delavirdinc was afforded by scveral observations. First, the $\mathrm{CL}_{\text {form }} / \mathrm{CL}_{\text {met }}$ ratio was reduced by about $40 \%$ to $50 \%$ at the larger dose rates (Table II). Thus, as the daily dose of delavirdine increased, the $\mathrm{N}$-dealkylated metabolite of delavirdine was formed less efficiently relative to the amount of delavirdine present in the systemic circulation. Second, the delavirdine half-life increased by about $30 \%$ to $60 \%$ as the dose rate increased, yet the drug's apparent volume of distribution was unchanged $\left[\mathrm{V}_{\mathrm{z}} / \mathrm{F}=(\mathrm{CL} / \mathrm{F}) / \lambda_{\mathrm{z}}\right.$ : phase 1, 49.5 L; phase 2, 33.0 L; phase 3; $39.5 \mathrm{~L}$; $p=0.6514]$. Third, hepatic CYP3A activity, assessed directly by the ERMBT, was shown to be inhibited by delavirdine (Table VI and Fig. 3). Changes in systemic availability alone would not account for the combined alterations in delavirdine's oral clearance, $\mathrm{CL}_{\mathrm{form}} / \mathrm{CL}_{\mathrm{met}}$, and half-life. However, increased drug levels as a consequence 
Group 1

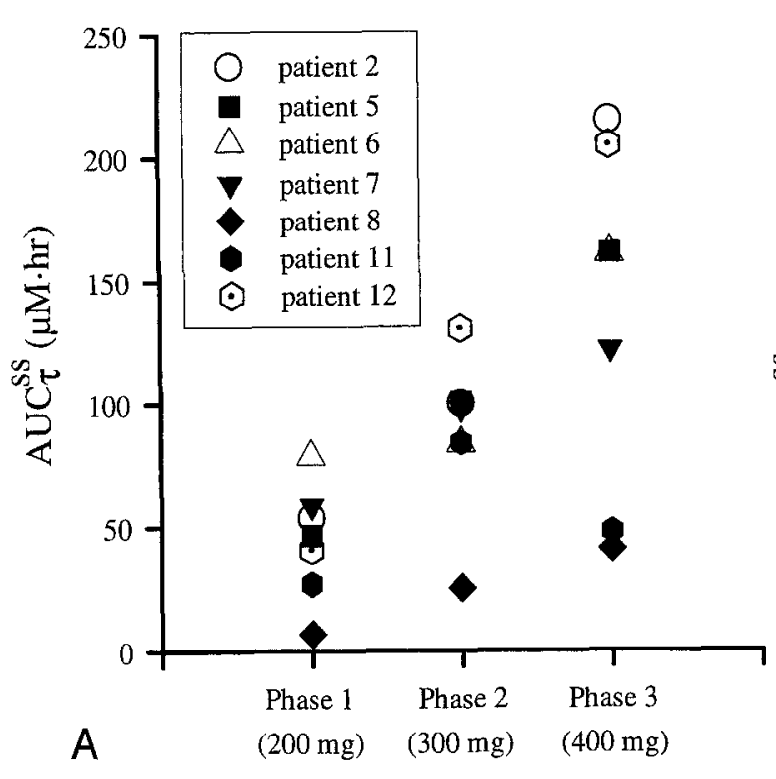

Group 1

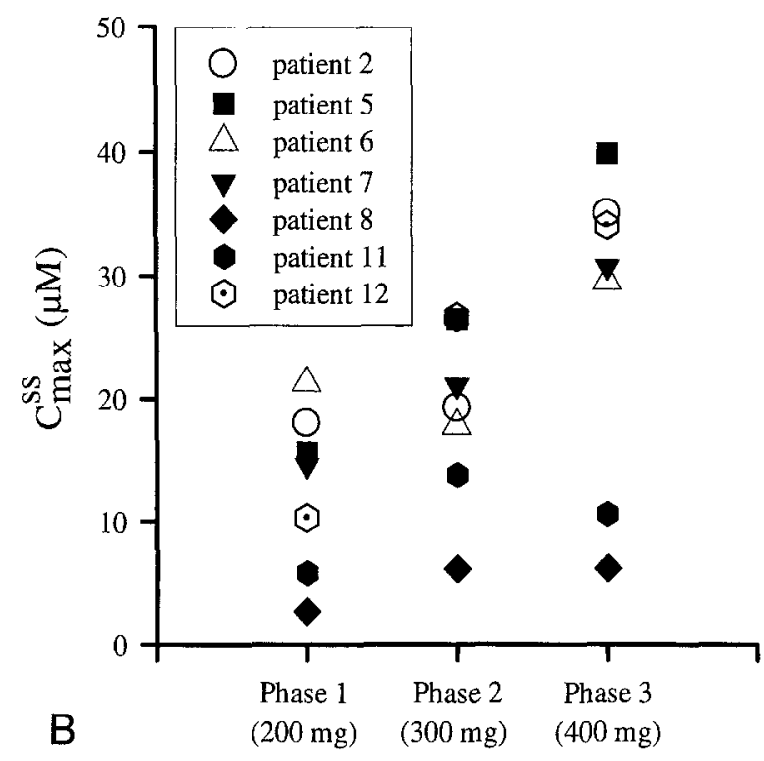

Group 2

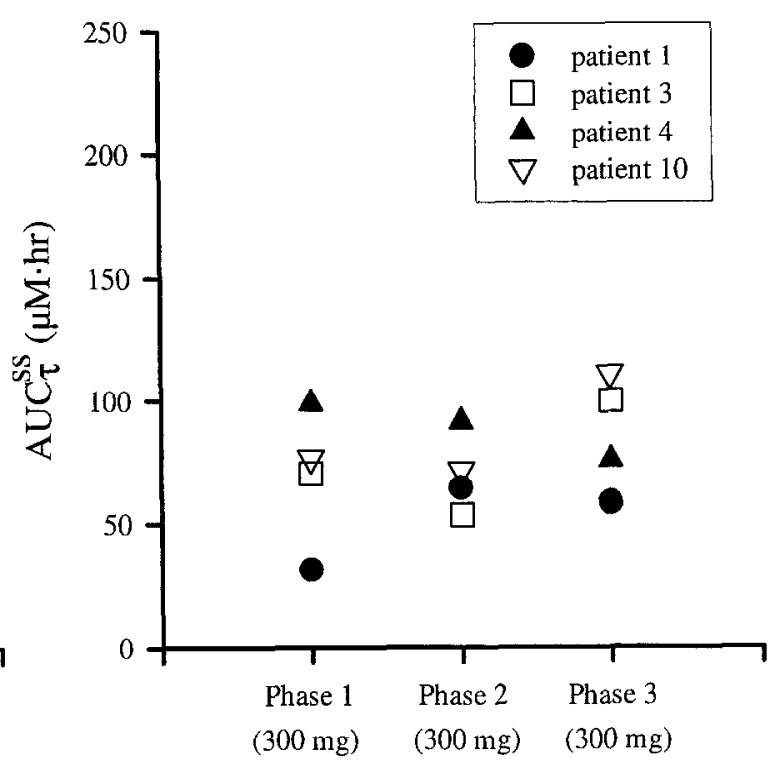

Group 2

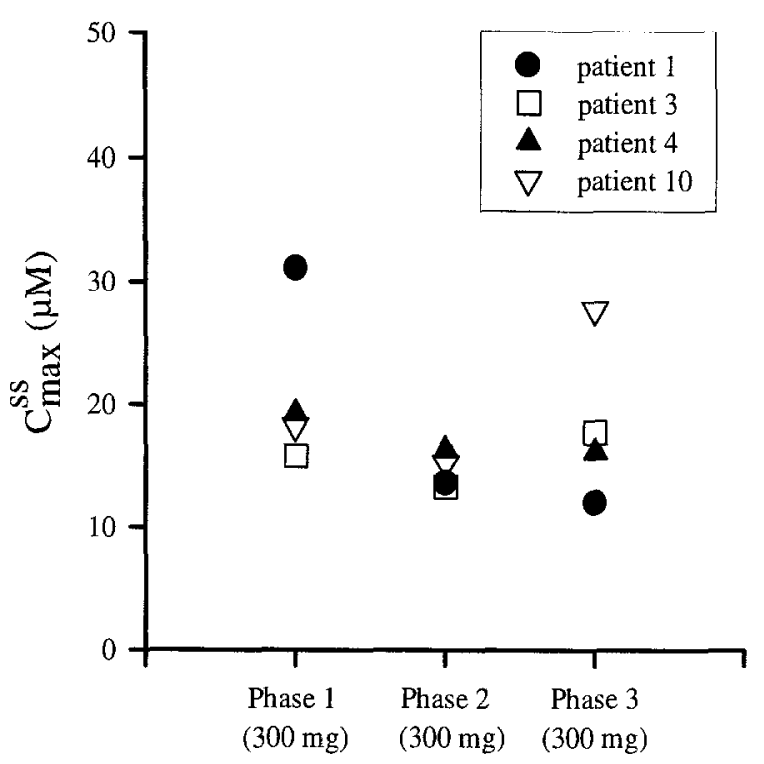

Hig. 7. Relationship between delavirdine steady-state area under the plasma concentrationtime curve $\mathrm{AUC}_{\tau}^{\mathrm{ss}}$ versus dose (A) and delavirdine maximum steady-state plasma concentration $\mathrm{C}_{\max }^{\text {ss }}$ versus dose (B) for the escalating-dose (group 1) and control (group 2) patients.

of more drug being absorbed or less drug being removed by presystemic metabolism in the gut and liver could cause a subsequent effect on the total plasma clearance of delavirdine. As a result, the po- tential for a dose-dependent increase in delavirdine's bioavailability cannot be ruled out at the present time.

Nonlinear kinetics were observed in the escalating-dose group for the desisopropyl metabo- 
lite of delavirdine, as noted previously (Table III). Although the reason for a dose-dependent half-life of desisopropyl-delavirdine is unclear at present, it is possible that another delavirdine metabolite (e.g., hydroxydelavirdine) is competing for the same metabolic pathway (e.g., sulfation). Further, the longer half-life of desisopropyl-delavirdine, compared with parent drug, suggests that the plasma decay of this metabolite is rate limited by its own elimination.

As observed in Fig. 4, delavirdine exposure resulted in a rapid and potent decrease in hepatic CYP3A activity, reaching a maximum inhibitory effect at delavirdine plasma concentrations of about 5 $\mu \mathrm{mol} / \mathrm{L}$ or greater. Because the average steady-state levels of delavirdine in all treatment groups were $>5$ $\mu \mathrm{mol} / \mathrm{L}$ on average, oral doses of 200,300 , or 400 $\mathrm{mg}$ delavirdine (given three times a day) are sufficient to produce a potent inhibition of CYP3A in liver. The maximal inhibitory effect of delavirdine was estimated at $70 \%$ to $75 \%$. The other $25 \%$ to $30 \%$ of metabolic activity not affected by delavirdine probably represents extrahepatic CYP3A and additional CYP450 isoforms in the liver or elsewhere.

In summary, the following conclusions can be made from this study: (1) the steady-state kinetics of delavirdine and desisopropyl-delavirdine remained unchanged after repeated oral administrations of drug at the same dose level, (2) the steady-state kinetics of delavirdine and desisopropyl-delavirdine wcre nonlincar aftcr escalating oral doses of dclavirdine mesylate, (3) delavirdine (or its metabolites) is a potent and reversible inhibitor of CYP3A in liver, (4) the $I_{\max }$ of delavirdine is $70 \%$ to $75 \%$ and its $\mathrm{IC}_{50}$ is about $0.9 \mu \mathrm{mol} / \mathrm{L}$, (5) CYP3A represents a major pathway for delavirdine $N$-dealkylation in vivo, and (6) delavirdine will probably cxhibit drugdrug interactions when coadministered with other CYP3A substrates.

Delavirdine mesylate (100 $\mathrm{mg}$ oral tablets) and radiolabeled delavirdine mesylate were provided by Pharmacia \& Upjohn, Inc. (Kalamazoo, Mich.). We thank Rachel Henegar and Cynthia Vansteenburg for their help with the clinical aspects of the study.

\section{References}

1. Althaus IW, Chou JJ, Gonzales AJ, Deibel MR, Chou KC, Kezdy FJ, et al. Steady-state kinetic studies with the non-nucleoside HIV-1 reverse transcriptase inhibitor U-87201E. J Biol Chem 1993;268:6119-24.

2. Campbcll TB, Young RK, Eron JJ, D'Aquila RT, Tarpley WG, Kuritzkes DR. Evaluation of the bisheteroarylpiperazine reverse transcriptase inhihitor
U-87201E in combination with zidovudine or didanosinc against HIV-1 infection in vitro. J Infect Dis 1993;168:318-26.

3. Dornsife RE, St Clair MH, Huang AT, Panella TJ, Koszalka GW, Burns CL, et al. Anti-human immunodeficiency virus synergism by zidovudine $\left(3^{\prime}\right.$ azidothymidine) and didanosine (dideoxyinosine) contrasts with their additive inhibition of normal human marrow progenitor cells. Antimicrob Agents Chemother 1991;35:322-8.

4. Dueweke TJ, Kezdy FJ, Waszak GA, Deibel MR, Tarpley WG. The binding of a novel bisheteroarylpiperazine mediates inhibition of human immunodeficiency virus type 1 reverse transcriptase. J Biol Chem 1992;267: 27-30.

5. Romero DL, Busso M, Tan CK, Reusser F, Palmer JR, Poppe SM, et al. Non-nucleoside reverse transcriptase inhibitors that potently and specifically block human immunodeficiency virus type 1 replication. Proc Natl Acad Sci USA 1991;88:8806-10.

6. Vasudevachari MB, Battista C, Lane HC, Psallidopoulos MC, Zhao B, Cook J, et al. Prevention of the spread of HIV-1 infection with non-nucleoside reverse transcriptase inhibitors. Virology 1992;190:26977.

7. Althaus IW, Chou JJ, Gonzales AJ, Deibel MR, Chou $\mathrm{KC}$, Kezdy FJ, et al. Kinetic studies with the nonnucleoside human immunodeficiency virus type-1 reverse transcriptase inhibitor U-90152E. Biochem Pharmacol 1994;47:2017-28.

8. Cox SR, Batts DH, Ward P, Freimuth WW, Staton $\mathrm{BA}$, Peel BG, et al. Escalating single and multiple dose safety, tolerance and pharmacokinetics (PK) of delavirdine mesylate (DLV, U-90152S) in normal volunteers [abstract]. National Conference on Human Retroviruses and Related Infections, December 1216, 1993:158.

9. Batts DH, Freimuth WW, Cox SR, Peel BG, Hanover $\mathrm{CK}$, Wathen LK, et al. Open-label escalating multiple-dose study of the safety, tolerance, and pharmacokinetics of oral U-90152S (delavirdine, DLV) in HIV-1 infected males and females with CD4 counts of 200 to $500 / \mathrm{mm}^{3}$, who are maintained on a stable dose of AZT [abstract]. National Conference on Human Retroviruses and Related Infections, December 1216, 1993:158.

10. Voorman RL, Maio SM, Wang X. Mechanism-based inactivation of rat and human cytochrome $\mathrm{P} 4503 \mathrm{~A}$ by delavirdine. Ninth International Conference on Cytochrome P450, Zurich, Switzerland, July 23-27, 1995.

11. Pichard L, Fabre I, Fabre G, Domergue J, Saint Aubert B, Mourad G,et al. Cyclosporin A drug interactions: screening for inducers and inhibitors of cytochromc P-450 (cyclosporin A oxidase) in primary cultures of human hepatocytes and in liver microsomes. Drug Metab Dispos 1990;18:595-606. 
12. Watkins PB, Murray SA, Winkelman LG, Heuman DM, Wrighton SA, Guzelian PS. Erythromycin breath test as an assay of glucocorticoid-inducible liver cytochromes P-450: studies in rats and patients. J Clin Invest 1989;83:688-97.

13. Turgeon DK, Leichtman AB, Lown KS, Normolle DP, Deeb GM, Merion RM, et al. P450 3A activity and cyclosporine dosing in kidney and heart transplant recipients. Clin Pharmacol Ther 1994;56:253-60.

14. Welage LS, Carver PL, Revankar S, Pierson C, Kauffman CA. Alterations in gastric acidity in patients with human immunodeficiency virus. Clin Infect Dis 1995; 21:1431-8.

15. Dressman JB. Comparison of canine and human gastrointestinal physiology. Pharm Res 1986;3:123-31.

16. Mojaverian P, Vlasses PH, Parker S, Warner C. In- fluence of single and multiple doses of oral ranitidine on the gastric transit of an indigestible capsule in humans. Clin Pharmacol Ther 1990;47:382-8.

17. Staton BA, Johnson MG, Friis JM, Adams WJ. Simple, rapid and sensitive high-performance liquid chromatographic determination of delavirdine and its $\mathrm{N}$-desisopropyl metabolite in human plasma. J Chromatogr B 1995;668:99-106.

18. Rowland M, Tozer TN. Clinical pharmacokinetics: concepts and applications. 3rd ed. Baltimore: Williams \& Wilkins, 1995.

19. Tozer TN, Gambertoglio JG, Furst DE, Avery DS, Holford NHG. Volume shifts and protein binding estimates using equilibrium dialysis: application to prednisolone binding in humans. J Pharm Sci 1983; 72:1442-6.

\section{ON THE MOVE?}

Don't miss a single issue of the journal! To ensure prompt service when you change your address, please photocopy and complete the form below.

Please send your change of address notification at least six weeks before your move to ensure continued service. We regret we cannot guarantee replacement of issues missed due to late notification.

\section{JOURNAL TITLE:}

Fill in the title of the journal here.

\section{OLD ADDRESS:}

Affix the address label from a recent issue of the journal here.

\section{NEW ADDRESS:}

Clearly print your new address here.

Name

Address

City/State/ZIP
COPY AND MAIL THIS FORM TO: Journal Subscription Services Mosby-Year Book, Inc. 11830 Westline Industrial Dr. St. Louis, MO 63146-3318
OR FAX TO:
$314-432-1158$

NM Mosby
OR PHONE:

1-800-453-4351

Outside the U.S., call

314-453-4351 